\title{
Sexuality in women with polycystic ovary syndrome: a pilot study
}

\author{
Sexualidade em mulheres com ovários policísticos: estudo piloto
}

\author{
Jucilene Sales da Paixão Silva ${ }^{1}$, Angela Maggio da Fonseca ${ }^{2}$, Vicente Renato Bagnoli ${ }^{3}$, Ana Lucia Cavalcanti ${ }^{4}$, \\ José Maria Soares $\mathrm{Jr}^{5}$, Edmund Chada Baracat ${ }^{6}$
}

\begin{abstract}
Objective: The objective of this study was to evaluate the sexual behavior of women with polycystic ovary syndrome and the relationship between sexual behavior and the clinical parameters related to this syndrome (obesity, hirsutism and menstrual irregularities). Methods: A cross-sectional study was carried out involving 48 women with polycystic ovary syndrome. The evaluation was based on the complaints reported by the women with particular emphasis on sexual satisfaction, the presence of a sexual partner, phases of the sexual response cycle (desire, arousal, orgasm and resolution phases), sexual frequency, practice of masturbation, evaluation of less usual sexual habits, degree of intimacy and the quality of communication in the women's involvement with their sexual partner. The variables of sexual behavior (sexual satisfaction, masturbation, sexual fantasies, frequency of desire, arousal and orgasm) were compared with three clinical parameters: menstrual cycle, hirsutism and body mass index (BMI). Results: The sexual initiation, ways of expressing sexuality, communication and intimacy with partner and sexual satisfaction were not influenced by the clinical aspects of the syndrome. With respect to association of polycystic ovary syndrome clinical parameters with sexual behavior, a statistically significant correlation was found with the menstrual cycle. Conclusion: The absence of menstruation affected sexual interest in activities not involving the partner, thus increasing the frequency of masturbation.
\end{abstract}

Keywords: Polycystic ovary syndrome; Sexuality; Sexual behavior

\section{RESUMO}

Objetivo: 0 objetivo deste estudo foi avaliar o comportamento sexual em mulheres com síndrome dos ovários policísticos e a relação de comportamento sexual e parâmetros clínicos relacionados a essa síndrome (obesidade, hirsutismo e irregularidade menstrual). Métodos: Um estudo transversal foi realizado com 48 mulheres com síndrome dos ovários policísticos. A avaliação foi baseada nas queixas referidas pelas pacientes com ênfase na satisfação sexual, existência ou não de parceiro, fases do ciclo da resposta sexual (desejo, excitação orgasmo e resolução), frequência sexual, prática de masturbação, avaliação de práticas sexuais menos habituais, grau de intimidade e qualidade de comunicação no envolvimento com 0 parceiro. As variáveis do comportamento sexual (satisfação sexual, masturbação, fantasia sexual, frequências de desejo, de excitação e de orgasmo) foram comparadas com três parâmetros clínicos: ciclo menstrual, hirsutismo e índice de massa corporal. Resultados: A iniciação sexual, as formas de expressão da sexualidade, a intimidade comunicativa com o parceiro e a satisfação sexual não foram influenciadas pela síndrome. Em relação à associação dos parâmetros clínicos da síndrome dos ovários policísticos com o comportamento sexual, correlação estatisticamente significativa foi encontrada com o ciclo menstrual. Conclusão: A ausência de menstruação exerceu impacto sobre 0 interesse sexual não vinculado às atividades com 0 parceiro, aumentando a frequência de masturbação.

Descritores: Síndrome do ovário policístico; Sexualidade; Comportamento sexual

\section{INTRODUCTION}

Sexual behavior commonly refers to the types of sexual activities in which a person engages. It is used to refer to an immense variety of activities, such as kissing and caressing, vaginal penetration, oral sex, anal sex, fantasies,

\footnotetext{
Study carried out at the Outpatients Clinic of the Gynecological Endocrinology and Climacteric Department of Universidade de São Paulo - USP, São Paulo (SP), Brazil.

1 PhD in Medicine, Universidade de São Paulo - USP, São Paulo (SP), Brazil.

${ }^{2}$ Post-doctorate degree, Universidade de São Paulo - USP, São Paulo (SP), Brazil.

${ }^{3}$ Post-doctorate degree, Universidade de São Paulo - USP, São Paulo (SP), Brazil.

${ }^{4} \mathrm{PhD}$ in Medicine, Universidade de São Paulo - USP, São Paulo (SP), Brazil.

${ }^{5}$ Post-doctorate degree, Universidade de São Paulo - USP, São Paulo (SP), Brazil.

${ }^{6}$ Post-doctorate degree; Full professor of the Gynecology Department at Universidade de São Paulo - USP, São Paulo (SP), Brasil.

Corresponding author: Jucilene Sales da Paixão Silva - Rua Dr. Mário Cardim, 463 - Vila Mariana - CEP $04019-000$ - São Paulo (SP), Brasil - Tel.: 11 3375-7562 - e-mail: jsdps@uol.com.br

Received on March 31, 2010 - Accepted on 0ct 13, 2010

Conflict of interest: None.
} 
masturbation and other manifestations. It involves a complex process with biological, psychological and interpersonal determinants. If any of these factors is compromised, sexuality and consequently the individual's quality of life may be affected ${ }^{(1)}$. Therefore, increasingly more studies have been carried out to evaluate aspects related to sexual health and to identify factors that positively or negatively affect woman's sexual satisfaction.

Polycystic ovary syndrome (PCOS) is the most common endocrine disorder in women during reproductive age, occurring in 4-7\% of women of this age group $^{(2,3)}$. It is characterized as an anatomical abnormality of the ovaries and includes associated disturbances of the neuroendocrine reproductive axis, such as increased androgen secretion, persistent anovulation and a heterogenous spectrum of etiological factors, clinical manifestations and endocrine disorders ${ }^{(4)}$.

Patients with PCOS have biopsychosocial alterations that may affect sexual function. Many aspects of this disorder may cause emotional stress ${ }^{(5)}$. Changes in appearance, menstrual irregularity or absence of menstruation, difficulty in conceiving, disturbed sexual behavior and attitudes may result in psychological distress and may affect the feminine identity of patients with $\operatorname{PCOS}^{(6,7)}$.

The important role of sexual steroids in the modulation of sexual function in women is well known. Receptors for these hormones (androgens, estrogens and progesterone) are found in the brain and also in genital tissues, suggesting that they are important both in central (desire, arousal) and peripheral sexual function $^{(8)}$.

Androgens appear to be the most important hormones in woman's sexuality, and an increase in susceptibility to the psychosocial stimuli that contribute towards "a sexually active mental state", typical of a good libido, has also been described, as well as enhancement of the oxide nitric pathway, leading to clitoral congestion and a greater intensity of sexual gratification ${ }^{(9)}$.

\section{OBJECTIVE}

The objective of this study was to evaluate the sexual behavior of women with PCOS and the relation of sexual behavior to the clinical parameters of the syndrome (obesity, hirsutism and irregular menstrual cycles).

\section{METHODS}

A cross-sectional pilot study was carried out involving 48 Brazilian women with PCOS seen at the Outpatients Clinic of the Gynecological Endocrinology and Climacteric Department - Universidade de São Paulo. The study was conducted from June 2007 to May
2009. All participants presented chronic anovulation (oligomenorrhea - menstrual cycle $\geq 35$ days with only four to nine periods per year, or amenorrhea no vaginal bleeding for $\geq 3$ months in individuals who previously had experienced periodic menstruation) and clinical manifestations of hyperandrogenism (acne and hirsutism - Ferriman-Gallwey score $>8$ ) and elevated androstenedione or testosterone, and polycystic ovaries detected by ultrasonography, as indicated by the presence of ovaries with 12 or more follicles measuring $2-9 \mathrm{~mm}$ in diameter located at the periphery of the ovarian parenchyma, and ovarian volume $>10 \mathrm{~cm}^{3}$. Secondary causes of hyperandrogenism were excluded.

Exclusion criteria was the presence of any systemic, psychiatric or endocrine disease, morbid obesity and the use of hormone therapy or any medication that could interfere with the sexual response cycle in the six months preceding enrollment to the trial.

All patients signed informed consent forms after receiving a detailed explanation of the study protocol. The study was approved by the Internal Review Board of Universidade de São Paulo.

Mean age of patients was 25.6 \pm 4.6 years, ranging 18-35 years. Thirty-four women $(70.8 \%)$ were white, $13(27.1 \%)$ were black and $1(2.1 \%)$ was Asiatic. Twenty-four patients $(50 \%)$ were single, $15(31.3 \%)$ had a stable, live-in partner and $9(18.7 \%)$ were married. With respect to schooling, 42 patients $(87.5 \%)$ had some secondary education. The majority of the women in this study were Catholic (54.2\%) or Evangelical (33.4\%), a group that included Adventists, nondenominational Christians and Protestants. With respect to income, only 28 patients $(58.3 \%)$ had income of their own. Physical activity was practiced regularly $(\geq$ 3 times/week) by only 8 patients $(16.7 \%)$ and 7 women $(14.6 \%)$ reported having smoking habits.

The researchers considered some questions to determine the socio-demographic variables, lifestyle and habits and medical history for evaluation of these patients. The HC Sexual Questionnaire was used to assess sexual history ${ }^{(10,11)}$. This questionnaire was approved in some international studies ${ }^{(12-13)}$ and analyses important items such as: age at first sexual experience, first sexual partner, occurrence of any sexual problems during the first sexual encounter, sexual orientation) and current sexual activity with particular emphasis on sexual satisfaction, the presence of a partner, phases of the sexual response cycle (desire, arousal, orgasm and resolution phases), sexual frequency, practice of masturbation, evaluation of less usual sexual practices, and the degree of intimacy and quality of communication in the women's involvement with their partner.

Androgen levels were measured in serum by radioimmunoassay using an iodated tracer in the case of androstenedione $\left(\Delta_{4}\right)$, and normal values were defined 
as $0.4-2.7 \mathrm{ng} / \mathrm{ml}$; and by immunofluorometric assays in the case of testosterone $(\mathrm{T})$, normal values ranging from $<14$ to $98 \mathrm{ng} / \mathrm{dl}$.

The variables in sexual behavior such as sexual satisfaction, masturbation, sexual fantasies, frequency of desire, arousal, and orgasm were compared with three clinical parameters: the menstrual cycle, hirsutism and body mass index (BMI).

\section{Statistical analysis}

A descriptive analysis was carried out on the clinical parameters of PCOS and variables of sexual behavior. Results were expressed as absolute (n) and relative frequencies $(\%)$.

To analyze the association of clinical parameters and sexual behavior, the following non-parametric tests were performed: the $x^{2}$ test for homogeneity or Fisher's exact test.

Significance level of 5\% was adopted throughout the statistical analysis. The software programs Excel 2000 and SPSS for Windows version 13.0 were used in the analysis.

\section{RESULTS}

Table 1 shows the distribution of patients with respect to variables of sexual behavior linked to activities performed with their partner, with comments. The main complaint that motivated patients to visit the clinic was menstrual irregularity, which was reported by 36 patients $(75 \%)$. The mean age at menarche was $12.9 \pm 2.1$ years. For 29 patients (60.4\%), the experience of their first menstruation was good (they were pleased, felt like adults and had already been given information on menstruation), whereas for 19 women $(39.6 \%)$ the experience was bad (they were afraid, embarrassed and had not received adequate information prior to the event).

With respect to the menstrual cycle, 21 patients $(43.7 \%)$ were amenorrheic, 15 (31.3\%) had oligomenorrhea and $12(25 \%)$ had regular cycles. Nine patients $(18.7 \%)$ had already been pregnant.

Hirsutism was present in 38 patients $(79.2 \%)$ and mild to moderate acne in $25(52.1 \%)$. According to BMI, 25 patients $(52.1 \%)$ were classified as normal weight, 16 $(33.3 \%)$ as overweight and $7(14.6 \%)$ as obese. Twentythree women $(47.9 \%)$ had a waist-to-hip ratio $>0.8$. Clitoromegaly was detected in 18 patients $(37.5 \%)$.

Androstenedione levels were elevated in 41 patients $(85.4 \%)$ and testosterone in $12(25 \%)$.

The majority of patients reported that the first information they received about sex had been provided by their mother, school, teachers or friends. The mean age at which this initial information was received
Table 1. Variables of sexual behavior related to activities involving a partner

\begin{tabular}{|c|c|c|c|}
\hline Questions & & n & $\%$ \\
\hline \multirow[t]{2}{*}{ Satisfactory sexual intercourse? } & Yes & 27 & 73 \\
\hline & No & 10 & 27 \\
\hline \multirow[t]{3}{*}{ Frequency of sexual intercourse per week? } & Not sexually active & 1 & 2.6 \\
\hline & Once or twice & 23 & 60.5 \\
\hline & $\geq 3$ times & 14 & 36.9 \\
\hline \multirow{4}{*}{$\begin{array}{l}\text { Frequency of desire/previous } 10 \text { occasions } \\
\text { on which sexual intercourse took place? }\end{array}$} & 0 & 1 & 2.7 \\
\hline & 1 - 5 occasions & 9 & 24.3 \\
\hline & $6-9$ occasions & 16 & 43.3 \\
\hline & 10 occasions & 11 & 29.7 \\
\hline \multirow{4}{*}{$\begin{array}{l}\text { Frequency of arousal/previous } 10 \text { occasions } \\
\text { in which sexual intercourse took place? }\end{array}$} & 0 & 1 & 2.7 \\
\hline & 1 - 5 occasions & 9 & 24.3 \\
\hline & $6-9$ occasions & 9 & 24.3 \\
\hline & 10 occasions & 18 & 48.7 \\
\hline \multirow{4}{*}{$\begin{array}{l}\text { Frequency of orgasm/previous } 10 \\
\text { occasions in which sexual intercourse took } \\
\text { place? }\end{array}$} & 0 & 4 & 10.8 \\
\hline & 1 - 5 occasions & 13 & 35.2 \\
\hline & 6 - 9 occasions & 11 & 29.7 \\
\hline & 10 occasions & 9 & 24.3 \\
\hline \multirow{4}{*}{$\begin{array}{l}\text { Frequency of masturbation with partner/ } \\
\text { previous } 10 \text { occasions in which sexual } \\
\text { intercourse took place }\end{array}$} & 0 & 5 & 13.5 \\
\hline & 1 - 5 occasions & 20 & 54.1 \\
\hline & 6 - 9 occasions & 9 & 24.3 \\
\hline & 10 occasions & 3 & 8.1 \\
\hline \multirow[t]{2}{*}{ Do you like to caress your partner? } & Yes & 38 & 100 \\
\hline & No & 0 & 0 \\
\hline \multirow[t]{2}{*}{ Do you like to be caressed by your partner? } & Yes & 38 & 100 \\
\hline & No & 0 & 0 \\
\hline \multirow{2}{*}{$\begin{array}{l}\text { Are you satisfied with your partner as a } \\
\text { friend? }\end{array}$} & Yes & 37 & 97.4 \\
\hline & No & 1 & 2.6 \\
\hline \multirow{2}{*}{$\begin{array}{l}\text { Are you satisfied with your partner as a } \\
\text { lover? }\end{array}$} & Yes & 33 & 86.8 \\
\hline & No & 5 & 13.2 \\
\hline \multirow{3}{*}{$\begin{array}{l}\text { What are the reasons that sustain your } \\
\text { relationship? }\end{array}$} & Friendship/love & 23 & 60.5 \\
\hline & Family/Habit & 14 & 36.9 \\
\hline & Financial & 1 & 2.6 \\
\hline \multirow[t]{3}{*}{ Duration of relationship? } & $<1$ year & 11 & 28.9 \\
\hline & $>1$ year and $<5$ years & 12 & 31.6 \\
\hline & $>5$ years & 15 & 39.5 \\
\hline \multirow{2}{*}{$\begin{array}{l}\text { Do you talk openly about sex with your } \\
\text { partner? }\end{array}$} & Yes & 26 & 68.4 \\
\hline & No & 12 & 31.6 \\
\hline \multirow{4}{*}{$\begin{array}{l}\text { How often do you take the initiative/ } \\
\text { previous } 10 \text { occasions in which sexual } \\
\text { intercourse took place }\end{array}$} & 0 & 11 & 29.7 \\
\hline & 1 - 5 occasions & 24 & 64.9 \\
\hline & 6 - 9 occasions & 2 & 5.4 \\
\hline & 10 occasions & 0 & 0 \\
\hline \multirow[t]{3}{*}{ How do you take the initiative? } & Caresses & 19 & 73.1 \\
\hline & Caresses and verbal & 6 & 23.1 \\
\hline & Verbal & 1 & 3.8 \\
\hline \multirow{2}{*}{$\begin{array}{l}\text { Are you aware of the parts of your own } \\
\text { body that give you pleasure? }\end{array}$} & Yes & 33 & 86.8 \\
\hline & No & 5 & 13.2 \\
\hline \multirow{2}{*}{$\begin{array}{l}\text { Are you aware of the parts of your } \\
\text { partner's body that give him pleasure? }\end{array}$} & Yes & 30 & 78.9 \\
\hline & No & 8 & 21.1 \\
\hline
\end{tabular}

was $13.4 \pm 2.5$ years, and the mean age of patients at initiation of sexual activity was $18 \pm 3.2$ years.

The first sexual intercourse was positive for $76.7 \%$ of patients and negative for $23.3 \%$. In $68.2 \%$, coitus represented their first experience of orgasm; however, $31.8 \%$ reported having already experienced orgasm by 
masturbation. All patients in this study reported being heterosexual. Figure 1 illustrates the total number of partners with whom the patients had a sexual intercourse for at least six months.

Among 48 patients, $39(81.3 \%)$ were satisfied with their sexual life and $38(79.2 \%)$ had a partner. One of the patients, despite being in a relationship for ten years, reported not having sexual intercourse. Thirteen

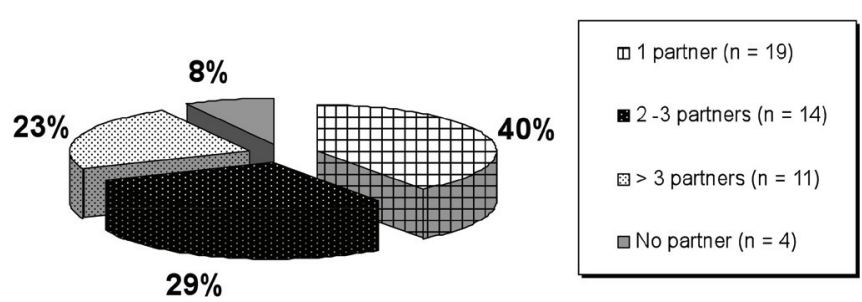

Figure 1. Number of partners with whom the 48 PCOS patients had a sexual relationship for at least 6 months

patients $(27.1 \%)$ reported masturbation, seven of whom reported masturbating once a week, two once every two weeks and four once a month. Sexual fantasies were reported by 16 patients $(33.3 \%)$.

Other variables studied showed pain during intercourse reported by 18 patients $(48.6 \%)$ and multiple orgasms by 17 (45.9\%). Other sexual practices included: fellatio, reported by 30 women $(81.1 \%)$, cunnilingus by
$31(83.8 \%)$ and anal intercourse, practiced by 9 patients $(24.3 \%)$.

Of the 11 abstinent patients, 5 reported lack of interest in investing in relationships (personal reasons) and 6 stated that the situation was exclusively consequence of not having a partner (external reason).

With respect to the relationship of clinical parameters of PCOS and sexual behavior, a statistically significant correlation $(\mathrm{p}=0.018)$ was found between menstrual cycle and masturbation. The percentage of women masturbating increased with the degree of irregularity of the menstrual cycle (Figure 2). No correlation was found between the variables of sexual behavior and hirsutism or BMI (Tables 2 and 3).

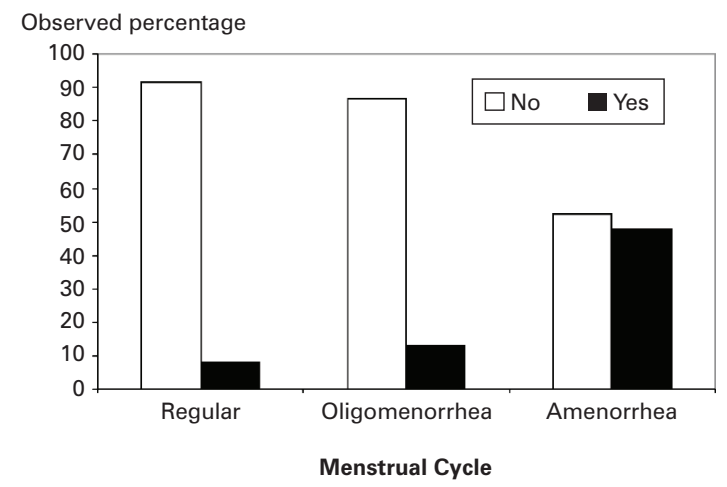

Figure 2. Relation between masturbation and menstrual cycle

Table 2. Relation between hirsutism and sexual behavior variables

\begin{tabular}{|c|c|c|c|c|c|c|c|c|}
\hline \multirow{3}{*}{$\begin{array}{l}\text { Variable } \\
\text { Masturbation }\end{array}$} & \multirow{3}{*}{$\begin{array}{c}\text { Category } \\
\text { No }\end{array}$} & \multicolumn{4}{|c|}{ Hirsutism } & \multirow{2}{*}{\multicolumn{2}{|c|}{ Total }} & \multirow{3}{*}{$\frac{\text { P value }}{>0.999^{*}}$} \\
\hline & & \multicolumn{2}{|c|}{ No } & \multicolumn{2}{|c|}{ Yes } & & & \\
\hline & & 7 & $70.0 \%$ & 28 & $73.7 \%$ & 35 & $72.9 \%$ & \\
\hline & Yes & 3 & $30.0 \%$ & 10 & $26.3 \%$ & 13 & $27.1 \%$ & \\
\hline Sexual satisfaction & No & 2 & $20.0 \%$ & 7 & $18.4 \%$ & 9 & $18.8 \%$ & $>0.999 *$ \\
\hline & Yes & 8 & $80.0 \%$ & 31 & $81.6 \%$ & 39 & $81.3 \%$ & \\
\hline Sexual fantasies & No & 7 & $70.0 \%$ & 25 & $65.8 \%$ & 32 & $66.7 \%$ & $>0.999 *$ \\
\hline Satisfactory sexual intercourse & No & 4 & $50.0 \%$ & 6 & $20.7 \%$ & 10 & $27.0 \%$ & $0.174^{*}$ \\
\hline & Yes & 4 & $50.0 \%$ & 23 & $79.3 \%$ & 27 & $73.0 \%$ & \\
\hline Total & & 8 & $100.0 \%$ & 29 & $100.0 \%$ & 37 & $100.0 \%$ & \\
\hline Frequency of desire/10 occasions of intercourse & 0 & 1 & $12.5 \%$ & 0 & $0.0 \%$ & 1 & $2.7 \%$ & 0.202 \\
\hline & $1-5$ & 2 & $25.0 \%$ & 7 & $24.1 \%$ & 9 & $24.3 \%$ & \\
\hline & $1-5$ & 2 & $25.0 \%$ & 7 & $24.1 \%$ & 9 & $24.3 \%$ & \\
\hline & $6-9$ & 1 & $12.5 \%$ & 8 & $27.6 \%$ & 9 & $24.3 \%$ & \\
\hline & 10 & 4 & $50.0 \%$ & 14 & $48.3 \%$ & 18 & $48.6 \%$ & \\
\hline Frequency of orgasm/10 occasions of intercourse & 0 & 2 & $25.0 \%$ & 2 & $6.9 \%$ & 4 & $10.8 \%$ & 0.267 \\
\hline & $1-5$ & 2 & $25.0 \%$ & 11 & $37.9 \%$ & 13 & $35.1 \%$ & \\
\hline & $6-9$ & 1 & $12.5 \%$ & 10 & $34.5 \%$ & 11 & $29.7 \%$ & \\
\hline & 10 & 3 & $37.5 \%$ & 6 & $20.7 \%$ & 9 & $24.3 \%$ & \\
\hline Total & & 8 & $100.0 \%$ & 29 & $100.0 \%$ & 37 & $100.0 \%$ & \\
\hline
\end{tabular}

* Fisher's exact test 
Table 3. Relation between body mass index (BMI) and sexual behavior variables

\begin{tabular}{|c|c|c|c|c|c|c|c|c|c|c|}
\hline \multirow{3}{*}{$\begin{array}{l}\text { Variable } \\
\text { Masturbation }\end{array}$} & \multirow{3}{*}{$\begin{array}{c}\text { Category } \\
\text { No }\end{array}$} & \multicolumn{6}{|c|}{ BMI } & \multirow{2}{*}{\multicolumn{2}{|c|}{ Total }} & \multirow{3}{*}{$\begin{array}{r}\text { P value } \\
0.149\end{array}$} \\
\hline & & \multicolumn{2}{|c|}{ Normal } & \multicolumn{2}{|c|}{ Overweight } & \multicolumn{2}{|c|}{ Obese } & & & \\
\hline & & 21 & $84.0 \%$ & 9 & $56.3 \%$ & 5 & $71.4 \%$ & 35 & $72.9 \%$ & \\
\hline & Yes & 4 & $16.0 \%$ & 7 & $43.8 \%$ & 2 & $28.6 \%$ & 13 & $27.1 \%$ & \\
\hline \multirow[t]{2}{*}{ Sexual satisfaction } & No & 4 & $16.0 \%$ & 4 & $25.0 \%$ & 1 & $14.3 \%$ & 9 & $18.8 \%$ & 0.731 \\
\hline & Yes & 21 & $84.0 \%$ & 12 & $75.0 \%$ & 6 & $85.7 \%$ & 39 & $81.3 \%$ & \\
\hline Sexual fantasies & No & 16 & $64.0 \%$ & 11 & $68.8 \%$ & 5 & $71.4 \%$ & 32 & $66.7 \%$ & 0.913 \\
\hline \multirow[t]{2}{*}{ Satisfactory sexual intercourse } & No & 5 & $23.8 \%$ & 3 & $30.0 \%$ & 2 & $33.3 \%$ & 10 & $27.0 \%$ & 0.871 \\
\hline & Yes & 16 & $76.2 \%$ & 7 & $70.0 \%$ & 4 & $66.7 \%$ & 27 & $73.0 \%$ & \\
\hline Total & & 21 & $100.0 \%$ & 10 & $100.0 \%$ & 6 & $100.0 \%$ & 37 & $100.0 \%$ & \\
\hline \multirow[t]{2}{*}{ Frequency of desire/10 occasions of intercourse } & 0 & 1 & $4.8 \%$ & 0 & $0.0 \%$ & 0 & $0.0 \%$ & 1 & $2.7 \%$ & 0.749 \\
\hline & $1-5$ & 6 & $28.6 \%$ & 3 & $30.0 \%$ & 0 & $0.0 \%$ & 9 & $24.3 \%$ & \\
\hline \multirow{3}{*}{ Frequency of arousal/10 occasions of intercourse } & $1-5$ & 8 & $38.1 \%$ & 1 & $10.0 \%$ & 0 & $0.0 \%$ & 9 & $24.3 \%$ & \\
\hline & $6-9$ & 4 & $19.0 \%$ & 2 & $20.0 \%$ & 3 & $50.0 \%$ & 9 & $24.3 \%$ & \\
\hline & 10 & 9 & $42.9 \%$ & 6 & $60.0 \%$ & 3 & $50.0 \%$ & 18 & $48.6 \%$ & \\
\hline \multirow[t]{4}{*}{ Frequency of orgasm/10 occasions of intercourse } & 0 & 2 & $9.5 \%$ & 1 & $10.0 \%$ & 1 & $16.7 \%$ & 4 & $10.8 \%$ & 0.704 \\
\hline & $1-5$ & 9 & $42.9 \%$ & 3 & $30.0 \%$ & 1 & $16.7 \%$ & 13 & $35.1 \%$ & \\
\hline & $6-9$ & 6 & $28.6 \%$ & 2 & $20.0 \%$ & 3 & $50.0 \%$ & 11 & $29.7 \%$ & \\
\hline & 10 & 4 & $19.0 \%$ & 4 & $40.0 \%$ & 1 & $16.7 \%$ & 9 & $24.3 \%$ & \\
\hline Total & & 21 & $100.0 \%$ & 10 & $100.0 \%$ & 6 & $100.0 \%$ & 37 & $100.0 \%$ & \\
\hline
\end{tabular}

\section{DISCUSSION}

Polycystic ovary syndrome, in addition to being a frequent disorder, is usually diagnosed at a young age when many sex-related issues are present and when stable relationships have not been established yet.

Sexuality is an integral part of health and well-being. The female sexuality is more complex and the lack of well-designed epidemiological studies and the use of different tools to assess Female Sexual Dysfunction (FSD) limit interpretation of results and conclusions in this area ${ }^{(14)}$.

The evaluation of sexual behavior of patients with PCOS is important from an academic point of view to increase the understanding of the role of androgens in female sexual function, and also in clinical practice to improve quality of care offered to these patients.

The majority of studies that have been carried out aimed to measure the effects exerted by PCOS on the quality of life of patients and on sexual initiation, frequency and satisfaction ${ }^{(15-19)}$. Sexuality, however, is more comprehensive than this, and the objective of this study was, therefore, to evaluate the sexual behavior of these women.

In this study, the main complaint that led patients to seek consultation at the clinic was menstrual irregularity. Analyzing the statistically significant correlation between menstrual irregularity and self-masturbation, the greater frequency of this practice by amenorrheic patients is clear. There was no correlation, however, between this finding and plasma androgen levels (androstenedione and testosterone) or with individual characteristics, such as marital status, personal income, religion or the existence or not of a partner.

The fact that menstrual irregularity has a significant effect on a variable that is not connected to sexual activities with a partner, while not having the same effect on variables associated with sexual activities involving the partner, may be related to the greater complexity of sexual activities developed as a couple and to the greater influence of psychological and interpersonal factors in the activity as a couple compared to solitary $\operatorname{activities}^{(20)}$.

Kaplan ${ }^{(21)}$ reported that, although orgasms achieved through masturbation are rarely as pleasurable or exciting as those experienced with a partner, for many women self-masturbation constitutes the easiest and most reliable way of reaching orgasm.

A negative effect of menstrual problems on the quality of life of patients has been previously discussed by other authors ${ }^{(22)}$ and is consistent with the notion that patients with PCOS suffer from "low feminine identity"(6).

In the vast majority of cases, the first information that these patients received with respect to sex was 
provided by their mother or by teachers at school. These findings reflect the fact that information received from parents and teachers has increased over recent decades. Trent et al. ${ }^{(15)}$ investigated adolescent patients with PCOS and also failed to find any statistically significant difference between the mean age of sexual initiation of this group of women compared to a control group of healthy adolescents.

With respect to marital status, half of the patients were married and/or living together with a partner, therefore with a presumed emotional stability, and $79.2 \%$ had a partner at the time of the interview. Agrawal et al. ${ }^{(23)}$ studied the prevalence of PCOS in lesbian women and found the syndrome to be more prevalent among this group compared to heterosexual women. It was also observed that lesbian women with PCOS have higher levels of androgens compared to heterosexual women with PCOS. In Serbia, Vujovic et al. ${ }^{(24)}$ found a $14.4 \%$ prevalence of PCOS among female-to-male transsexuals, and it was higher than in the general population. Based on these results, it was suggested that high concentrations of androgens usually seen in patients with PCOS may contribute with sexual orientation. In this study, however, all patients were heterosexual.

Contradicting data reported by Elsenbruch et al. ${ }^{(17)}$ and Hahn et al. ${ }^{(18)}$, the rate of sexual satisfaction is a complex phenomenon, resulting from the conformity of an individual with his/her sexual requirements and motivations, conception of values and objectives, as well as his/her sexual experiences, his/her own behavior and the behavior of others.

In the variables of sexual behavior related to activities performed with a partner, no correlation was found between the main clinical manifestations of PCOS (irregular menses, hirsutism and obesity) and the variables related to the sexual response cycle. Similar results were reported by Battaglia et al. ${ }^{(25)}$, who did not find significant differences in the incidence of sexual dysfunction between PCOS and control patients. In addition, the authors reported that there were no differences among data on the partners (partner's sexual health, feelings, relationship etc.) indicating no different values between PCOS women and controls.

The frequency of sexual desire and arousal was considered adequate and satisfactory for the majority of patients. Nevertheless, $35.2 \%$ of patients were found to have some degree of difficulty in reaching orgasm and 4 were anorgasmic. In this study, we were interested more in the quality of the sexual activity rather than in numerical aspects. The rate of satisfaction with sexual intercourse was high, and the degree of intimacy and communication that the women maintained with their partner was also good. Studies on sexuality vary with respect to the value given to orgasm in sexual satisfaction $^{(26,27)}$.

Although this pilot study provides important data, the results must be interpreted with caution because larger and previously randomized samples with a control group are required.

\section{CONCLUSION}

In women with PCOS, sexual initiation, forms of expressing sexuality, intimate communication with their partners and sexual satisfaction were not affected by the syndrome. Nonetheless, the absence of menstruation had an effect on sexual interest in activities unrelated to their partner, increasing the frequency of masturbation.

\section{REFERENCES}

1. Bernhard LA. Sexuality and sexual health care for women. Clin Obstet Gynecol. 2002;45(4):1089-98.

2. Asuncion M, Calvo RM, San Millan JL, Sancho J, Avila S, Escobar-Morreale HF. A prospective study of the prevalence of the polycystic ovary syndrome in unselected Caucasian women from Spain. J Clin Endocrinol Metab. 2000;85(7):2434-8.

3. Franks S. Polycystic ovary syndrome. N Engl J Med. 1995;333(13):853-61.

4. Guzick DS. Polycystic ovary syndrome. Obstet Gynecol. 2004;103(1):181-93.

5. Eggers $S$, Kirchengast $S$. The polycystic ovary syndrome - a medical condicion but also an important psychosocial problem. Coll Antropol. 2001;25(2):673-85.

6. Kitzinger $\mathrm{C}$, Willmott J. "The thief of womanhood": women's experience of polycystic ovarian syndrome. Soc Sci Med. 2002;54(3):349-61.

7. Barnard L, Ferriday D, Guenther N, Staruss B, Balen AH, Dye L. Quality of life and psychological well being in polycystic ovary syndrome. Hum Reprod. 2007;22(8):2279-86.

8. Goldstein I, Traish A, Kim N, Munarriz R. The role of sex steroid hormones in female sexual function and dysfunction. Clin Obstet Gynecol. 2004;47(2):471-84.

9. Graziottin A. Libido: the biologic scenario. Maturitas. 2000;34 Suppl 1:S9-16.

10. Abdo CHN, Moreira JR, Fittipaldi JAS. Estudo do comportamento sexual no Brasil - ECOS. Rev Bras Med. 2000;57(11):1329-35.

11. Abdo CHN. Estudo da vida sexual do brasileiro. São Paulo: EVSB. Editora Bregantini; 2004.

12. Penteado SRL, Fonseca AM, Bagnoli VR, Abdo CHN, Soares JR JM, Baracat EC. Effects of the addition of methyltestosterone to combined hormone therapy with estrogens and progestogens on sexual energy and on orgasm in postmenopausal women. Climateric. 2008;11(1):17-25.

13. Penteado SRL, Fonseca AM, Bagnoli VR, Assis JS, Pinotti JA. Sexuality in healthy postmenopausal women. Climateric. 2003;6(4):321-9.

14. Hayes RD, Dennerstein L, Bennett CM, Fairley CK. What is the "true" prevalence of female sexual dysfunctions and does the way we assess these conditions have an impact? J Sex Med. 2008;5(4):777-87.

15. Raboch J, Kobilkovà J, Raboch J, Starka L. Sexual life of women with the Stein-Leventhal syndrome. Arch Sex Behav .1985;14(3):263-70.

16. Trent ME, Rich M, Austin SB, Gordon CM. Fertility concerns and sexual behavior in adolescent girls with polycystic ovary syndrome: implications for quality of life. J Pediatr Adolesc Gynecol. 2003;16(1):33-7.

17. Elsenbruch S, Hahn S, Kowalsky D, Offner AH, Schedlowski M, Mann K, et al. Quality of life, psychosocial well-being, and sexual satisfaction in women with polycystic ovary syndrome. J Clin Endocrinol Metab. 2003;88(12):5801-7. 
18. Hahn S, Janssen OE, Tan S, Pleger K, Mann K, Schedlowski M, et al. Clinical and psychological correlates of quality-of-life in polycystic ovary syndrome. Eur J Endocrinol. 2005;153(6):853-60.

19. Borges R, Temido P, Sousa L, Azinhais P, Conceição P, Pereira B, et al. Metabolic syndrome and sexual (dys)function. J Sex Med. 2009;6(11):2958-75.

20. Alexander GM, Sherwin BB, Bancroft J, Davidson DW. Testosterone and sexual behavior in oral contraceptive users and nonusers: a prospective study. Horm Behav. 1990;24(3):388-402.

21. Kaplan HS. The sexual desire disorders: dysfunctional regulation of sexual motivation. (CNew York: Brunner/Mazel; 1995.

22. McCook JG, Reame NE, Thatcher SS. Health-related quality of life issues in women with polycystic ovary syndrome. J Obstet Gynecol Neonatal Nurs. 2005;34(1):12-20.
23. Agrawal R, Sharma S, Bekir J, Conway G, Bailey J, Balen AH, et al. Prevalence of polycystic ovaries and polycystic ovary syndrome in lesbian women compared with heterosexual women. Fertil Steril. 2004;82(5):1352-7.

24. Vujovic S, Popovic S, Sbutega-Milosevic G, Djordjevic M, Gooren L. Transsexualism in Serbia: A twenty-year follow-up study. J Sex Med. 2009;6(4):1018-23.

25. Battaglia C, Nappi RE, Mancini F, Cianciosi A, Persico N, Busacchi P, et al. PCOS, sexuality, and clitoral vascularisation: a pilot study. J Sex Med. 2008;5(12):2886-94.

26. Waterman CK, Chiauzzi EJ. The role of orgasm in male and female sexual enjoyment. J Sex Res. 1982;18(2):146-59.

27. Darling CA, Davidson JK Sr, Cox RP. Female sexual response and the timing of partner orgasm. J Sex Marital Ther. 1991;17(1):3-21. 